\title{
Influence of application of retardants with pinoxaden on selected quality characteristics of winter wheat grain
}

\author{
Wpływ stosowania retardantów z pinoksadenem \\ na wybrane cechy jakościowe ziarna pszenicy ozimej
}

\author{
Wojciech Miziniak ${ }^{1 *}$, Kinga Matysiak², Agnieszka Kiniec ${ }^{1}$
}

\section{Summary}

The field trials were carried out at the Institute of Plant Protection - National Research Institute in the years 2010/2011 and 2012/2013. The experiments were established on winter wheat cultivar Alcazar. The aim of the study was to assess the effect of pinoxaden applied with plant growth regulators on the crop grain quality. The application of the tested products was performed at BBCH 24 growth stage of winter wheat (only herbicide) and mix application of pinoxaden with different growth regulators at the growth stage of BBCH 31 . In both years of research, pinoxaden (Axial $100 \mathrm{EC}$ ) positively affected the content of protein, gluten and the value of Zeleneg'o coefficient, while the mixture of herbicide with trinexapac ethyl decreased grain quality parameters. In the studies, no significant differences were found in the quality of wheat grain after the use of pinoxaden with chlormequat chloride and prohexadione of calcium. However, depending on the year, the mixture of pinoxaden with CCC or prohexadione of calcium increased or decreased grain quality parameters. In both years of study, no significant differences were found in the degree of hardness of the seeds between experimental treatments.

Key words: winter wheat; pinoxaden; trinexapak ethyl; cholomequat chloride; prohexadione calcium; grain quality

\section{Streszczenie}

Badania polowe prowadzono w latach 2010/2011 i 2012/2013, w Instytucie Ochrony Roślin - Państwowym Instytucie Badawczym, w pszenicy ozimej odmiany Alcazar. Aplikację badanych preparatów wykonano w fazie BBCH 24 pszenicy ozimej - tylko herbicyd oraz w fazie BBCH 31 - mieszanina pinoksadenu z retardantami wzrostu. W obydwu latach badań herbicyd (Axial 100 EC) wpłynął korzystnie na zawartość białka, glutenu oraz na wartość współczynnika Zeleneg'o, natomiast łączne stosowanie herbicydu z trineksapakiem etylu przyczyniło się do obniżenia jakości ziarna. W przeprowadzonych badaniach nie stwierdzono istotnych różnic w jakości ziarna pszenicy po zastosowaniu pinoksadenu z chlorkiem chloromekwatu lub z proheksadionem wapnia. Jednakże, w zależności od roku badań mieszaniny pinoksadenu z CCC lub proheksadionem wapnia podwyższały lub obniżały parametry jakościowe ziarna. W obydwu latach badań nie stwierdzono istotnych różnic w stopniu twardości ziarniaków pomiędzy obiektami badań.

Słowa kluczowe: pszenica ozima; pinoksaden; trineksapak etylu; chlorek chloromekwatu; proheksadion wapnia; jakość ziarna

\footnotetext{
${ }^{1}$ Instytut Ochrony Roślin - Państwowy Instytut Badawczy

Terenowa Stacja Doświadczalna w Toruniu

Pigwowa 16, 87-100 Toruń

${ }^{2}$ Instytut Ochrony Roślin - Państwowy Instytut Badawczy

Władysława Węgorka 20, 60-318 Poznań

*corresponding author: w.miziniak@iorpib.poznan.pl
} 


\section{Wstęp / Introduction}

Jakość technologiczna ziarna uzależniona jest między innymi od cech fizjologiczno-genetycznych (Rothkaehl 1995), czynników klimatycznych (Podolska i Stankowski 2001), poziomu nawożenia (Domska i Rogalski 1993), stosowanych zabiegów agrotechnicznych (Adamczewski i Praczyk 1997; Podolska i wsp. 2004) oraz od warunków przechowywania po zbiorze. Uzyskanie wysokiej jakości ziarna decyduje o wykorzystaniu plonu (Gil i wsp. 2003), a w ślad za tym o cenie skupu oraz rynkach zbytu (Domaradzki i Sekutowski 2004).

W dostępnej literaturze można znaleźć zróżnicowany pogląd dotyczący wpływu środków ochrony roślin na parametry jakościowe ziarna zbóż. Według większości zaprezentowanych opinii, zarówno herbicydy, jak i retardanty wzrostu mogą wpływać na pogorszenie jakości ziarna (Romek i Dzienia 1992; Krawczyk i wsp. 1995; Gil i wsp. 2003; Cacak-Pietrzak i wsp. 2005, 2006). Inny pogląd przedstawił Kucharski i wsp. (2012) wskazując na brak zależności, natomiast Leszczyńska i Nieróbca (2004) w przeprowadzonych badaniach wykazały podwyższenie parametrów jakościowych ziarna zbóż.

Intensyfikacja technologii uprawy roślin, zbliżone terminy aplikacji niektórych środków ochrony roślin, możliwości ograniczenia kosztów zabiegów oraz usprawnienie organizacji pracy $\mathrm{w}$ gospodarstwie rolnym, przyczyniły się do wdrożenia w nowoczesnym rolnictwie łącznego stosowania agrochemikaliów (Pruszyński i Mrówczyński 2002). Dodatkową korzyścią stosowania mieszanin zbiornikowych agrochemikaliów jest możliwość wystąpienia efektu synergistycznego pomiędzy poszczególnymi substancjami czynnymi, który w konsekwencji prowadzi do polepszenia efektywności ich działania. W pracach licznych autorów można znaleźć doniesienia o korzystnym wpływie mieszanin retardantów $\mathrm{CCC}$ i etefonu z nawozami dolistnymi na parametry jakościowe ziarna (Drzewiecki i Pietryga 2002, 2003; Pietryga i Drzewiecki 2003, 2004), benomylu z CCC (Maćkowiak i wsp. 2001) oraz paklobutrazolu z trineksapakiem etylu (Fidanza i wsp. 2006).

Celem pracy było określenie wpływu łącznego stosowania pinoksadenu z retardantami wzrostu na wybrane parametry jakościowe ziarna pszenicy ozimej odmiany Alcazar.

\section{Materiały i metody / Materials and methods}

Doświadczenia polowe przeprowadzono w latach 2010/ 2011 i 2012/2013, w pszenicy ozimej odmiany Alcazar, w układzie statystycznym losowanych bloków w czterech powtórzeniach. W sezonie wegetacyjnym 2011/2012 nie prowadzono obserwacji z powodu wymarznięcia rośliny uprawnej. Powierzchnia poletek wynosiła $12 \mathrm{~m}^{2}$. Zabiegi przeprowadzono $\mathrm{w}$ dwóch oddzielnych terminach: termin $\mathrm{A}$
(BBCH 24 pszenicy ozimej) - pinoksaden (Axial 100 EC) + metylowany olej rzepakowy (Adigor 440 EC) i termin $\mathrm{B}(\mathrm{BBCH} 31)$ mieszaniny pinoksadenu (Axial $100 \mathrm{EC}$ ) z retardantami wzrostu: trineksapakiem etylu (Moddus 250 EC), chlorkiem chloromekwatu (Antywylegacz płynny $725 \mathrm{SL}$ ), proheksadionem wapnia (Regalis $10 \mathrm{WG)}$ ) oraz tylko retardanty wzrostu $\mathrm{w}$ wariantach badań opryskiwanych w terminie A tylko herbicydem.

Obiekty badań szczegółowo przedstawiono poniżej:

1. kontrola,

2. pinoksaden + metylowany olej rzepakowy (termin A); trineksapak etylu (termin B),

3. pinoksaden + metylowany olej rzepakowy + trineksapak etylu (termin B),

4. pinoksaden + metylowany olej rzepakowy (termin A); chlorek chloromekwatu (termin B),

5. pinoksaden + metylowany olej rzepakowy + chlorek chloromekwatu (termin B),

6. pinoksaden + metylowany olej rzepakowy (termin A); proheksadion wapnia (termin B),

7. pinoksaden + metylowany olej rzepakowy + proheksadion wapnia (termin B),

8. pinoksaden + metylowany olej rzepakowy (termin A).

Aplikację wyżej wymienionych preparatów wykonano za pomocą opryskiwacza rowerowego typu „Victoria” wyposażonego $\mathrm{w}$ rozpylacze TEEJET $11002 \mathrm{VP}$ zużywając 2001 cieczy użytkowej w przeliczeniu na 1 ha, przy ciśnieniu roboczym $0,25 \mathrm{MPa}$. W obydwu latach badań przedplonem pszenicy ozimej był jęczmień jary. W trakcie wegetacji roślin zastosowano nawożenie mineralne na poziomie

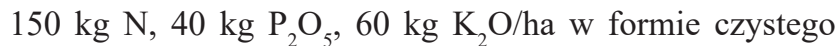
składnika oraz standardową ochronę przeciwko chorobom i szkodnikom. Analizę jakości ziarna przeprowadzono za pomocą analizatora Infratec TM 1241 (FOSS).

Analizie statystycznej poddano dane dotyczące zawartości białka, skrobi, glutenu, współczynnika Zelene'go oraz twardości ziarna. Wyniki testu Fishera oceniano na poziomie istotności 1 i 5\%. Po stwierdzeniu istotnych różnic dokonano szczegółowego porównania średnich za pomocą testu t-Studenta, wyznaczając najmniejszą istotną różnicę na poziomie istotności $5 \%$.

\section{Wyniki i dyskusja / Results and discussion}

Wartość technologiczna ziarna pszenicy ozimej uzależniona jest od cech fizjologiczno-genetycznych, które modyfikowane są przez warunki klimatyczne oraz zastosowaną agrotechnikę (Dubis i Borysewicz 2008). Według Podolskiej i Stankowskiego (2001) oraz Langensiepena i wsp. (2008), mniejsza suma opadów oraz wyższe temperatury powietrza wpływają na zwiększenie zawartości białka i glutenu oraz wartość współczynnika sedymentacyjnego Zeleneg'o w ziarnie pszenicy. Powyższa zależność została potwierdzo- 
na w przeprowadzonych badaniach. W 2011 roku, w okresie dojrzewania zboża zarejestrowano niższą temperaturę powietrza oraz wyższe opady niż w analogicznym okresie 2013 roku (tab. 1). W związku z tym, ziarno pszenicy pochodzące ze zbiorów 2011 roku odznaczało się niższymi parametrami jakościowymi (białko, gluten, współczynnik Zelene'go) niż ziarno zebrane w 2013 roku.

Według Gila i wsp. $(2003,2004)$ herbicydy zawierające propoksykarbazon sodowy i sulfosulfuron wpływają w zróżnicowany sposób na wartości przemiałowe mąki, powodując w niektórych latach niewielką obniżkę zawartości białka, glutenu mokrego oraz wskaźnika sedymentacji. W dwuletnich badaniach polowych odnotowano odmienne relacje. Ziarno pszenicy ozimej opryskiwanej pinoksadenem charakteryzowało się wyższą zawartością białka, glutenu oraz większym współczynnikiem sedymentacyjnym Zeleneg'o w porównaniu do ziarna pobranego z kontroli (tab. 2). Oprócz wymienionych czynników (warunki klimatyczne, herbicydy) parametry jakościowe ziarna zbóż mogą ulec modyfikacji w przypadku zastosowania regulatorów wzrostu. Większość doniesień zawartych w literaturze wskazuje na tendencję do zmniejszenia zawartości białka (Dziamba i Mikos 1987; Woźnica 1988; Cacak-Pietrzak i wsp. 2005, 2006), glutenu i liczby opadania (Leszczyńska i Grabiński 2003) po zastosowaniu retardantów w roślinach zbożowych.

Niezależnie od roku badań, mieszaniny pinoksadenu i trineksapaku etylu wpłynęły na obniżenie wartości technologicznej ziarna. W 2011 roku ziarno pszenicy ozimej zebrane z poletek opryskiwanych mieszaninami preparatów charakteryzowało nieznacznie mniejszą zawartością białka, glutenu oraz niższymi wartościami wskaźnika sedymentacyjnego Zelene'go niż pszenica pobrana z wariantów badań, w których aplikowano preparaty oddzielnie. Podobne zależności zaobserwowano w drugim roku badań. W porównaniu do pierwszego roku badań przeprowadzone obliczenia statystyczne dowiodły, że łączna aplikacja tych substancji czynnych w istotnym zakresie wpływa na obniżenie wyszczególnionych parametrów jakościowych ziarna. Inne relacje odnotowali Harasim i Wesołowski (2013). Według autorów trineksapak etylu nie wpływa w istotnym zakresie na parametry jakościowe ziarna pszenicy. Jednakże, wymienieni autorzy stwierdzili, że obniżone dawki retardanta wpływają na pogorszenie indeksu glutenu.

W pozostałych obiektach badań sposób aplikacji retardantów nie miał istotnego wpływu na oceniane parametry jakościowe ziarna. Pomimo braku istotnych różnic zarówno dodatek CCC (w roku 2011) i proheksadionu wapnia (w roku 2013) do herbicydu wpłynął na nieznaczne podwyższenie zawartości białka, glutenu oraz wskaźnika sedymentacyjnego Zelene'go. Zaistniałe relacje uwidoczniły się jedynie $\mathrm{w}$ jednym $\mathrm{z}$ dwóch lat badań. $\mathrm{W}$ odniesieniu do CCC, proheksadion wapnia stosowany łącznie z pinoksadenem wpłynął korzystnie na analizowane cechy w drugim roku badań (wyższa temperatura podczas dojrzewania zboża oraz mniejsze opady). Natomiast dla CCC korzystny wpływ mieszanin uwidocznił się w niższej temperaturze i większej ilości opadów (w roku 2011).

Uzyskane zależności są zbliżone do wyników badań zaprezentowanych przez Pawłowską i Dietrych-Szóstak

Tabela 1. Warunki pogodowe

Table 1. Weather conditions

\begin{tabular}{c|c|c|c|c}
\hline \multirow{2}{*}{$\begin{array}{c}\text { Miesiąc } \\
\text { Month }\end{array}$} & \multicolumn{4}{|c}{$\begin{array}{c}\text { Warunki pogodowe w poszczególnych latach badań } \\
\text { Weather conditions in the years of the studies }\end{array}$} \\
\cline { 2 - 5 } & \multicolumn{2}{|c}{$2010 / 2011$} & \multicolumn{2}{c}{$2012 / 2013$} \\
\cline { 2 - 5 } & $\begin{array}{c}\text { średnia temperatura } \\
\text { average temperature } \\
{\left[{ }^{\circ} \mathrm{C}\right]}\end{array}$ & $\begin{array}{c}\text { opady } \\
\text { rainfall } \\
{[\mathrm{mm}]}\end{array}$ & $\begin{array}{c}\text { średnia temperatura } \\
\text { average temperature } \\
{\left[{ }^{\circ} \mathrm{C}\right]}\end{array}$ & $\begin{array}{c}\text { } \\
\text { opady } \\
\text { rainfall } \\
{[\mathrm{mm}]}\end{array}$ \\
\hline IX & 12,6 & 74,4 & 14,1 & 37,6 \\
\hline X & 6,6 & 5,3 & 8,4 & 26,4 \\
\hline XI & 5,1 & 156,7 & 5,2 & 62,0 \\
\hline XII & $-6,1$ & 55,8 & $-2,6$ & 27,0 \\
\hline I & $-15,8$ & 23,7 & $-3,6$ & 63,6 \\
\hline II & $-2,5$ & 14,4 & $-1,5$ & 24,5 \\
\hline III & 5,1 & 10,4 & 7,7 & 40,1 \\
\hline IV & 12,0 & 11,3 & 15,3 & 19,0 \\
\hline V & 14,1 & 53,8 & 17,4 & 87,0 \\
\hline VI & 18,2 & 63,0 & 18,4 & 46,6 \\
\hline VII & 18,3 & 244,5 & 19,2 & 104,3 \\
\hline
\end{tabular}




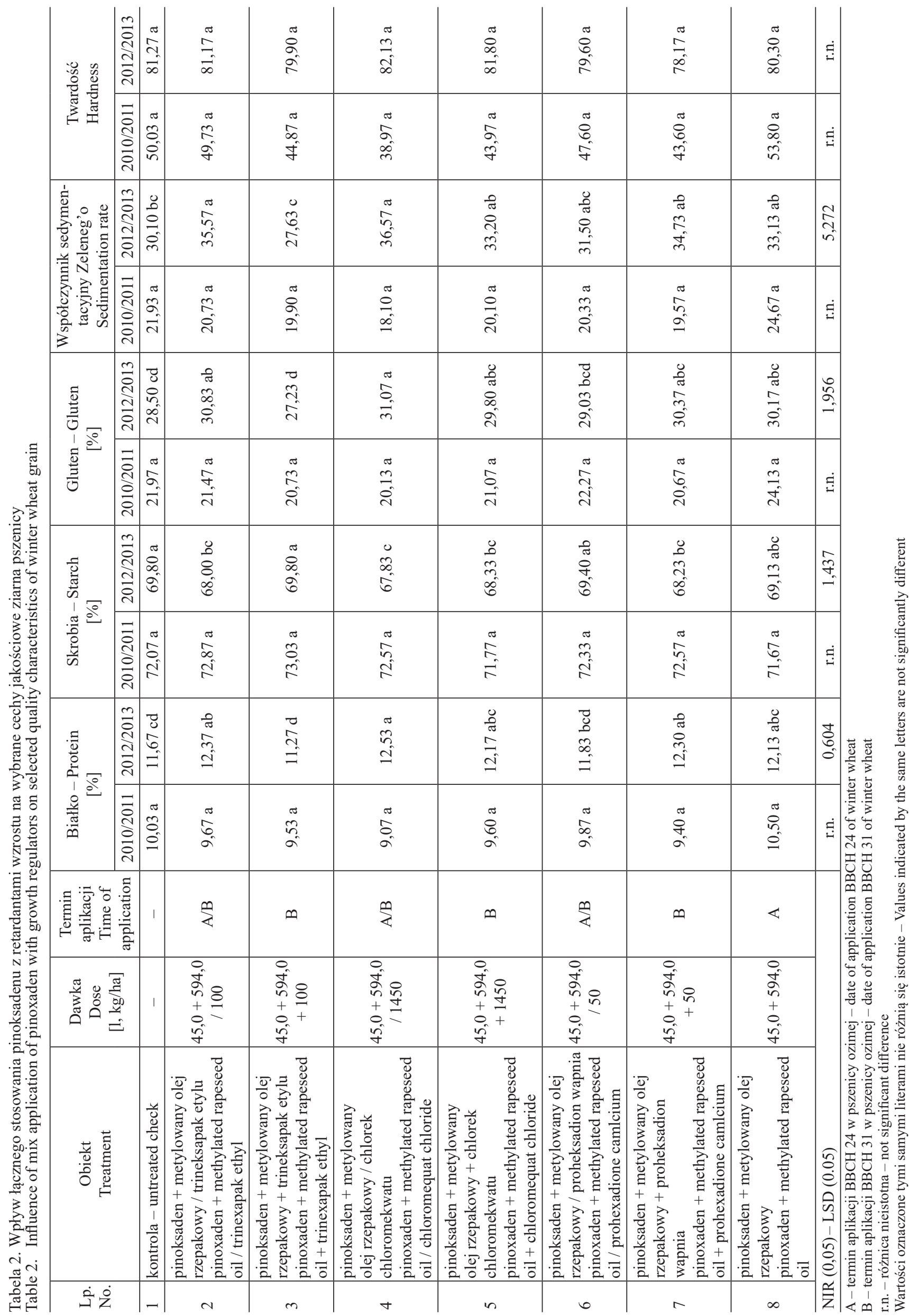


(1994). Według autorek zarówno Flordimex T, jak i CCC nie powodują istotnych zmian w zawartości białka w ziarnie. Podobne rezultaty przedstawiły Leszczyńska i Nieróbca (2004) wykazując brak wpływu retardantów wzrostu na ilość białka i wykształcenie ziarna przy nieznacznej tendencji do podwyższenia zawartości glutenu w ziarnie pszenicy ozimej.

W obydwu latach badań, w większości ocenianych wariantów badań nie stwierdzono istotnych różnic w zawartości procentowej skrobi w ziarnie pszenicy oraz w stopniu twardości ziarniaków.

\section{Wnioski / Conclusions}

1. W obydwu latach badań pinoksaden korzystnie wpłynął na zawartość białka, glutenu oraz na wartość współczynnika Zeleneg’o w porównaniu do kontroli.
2. Najmniej korzystne $\mathrm{z}$ punktu widzenia jakości ziarna było zastosowanie mieszaniny trineksapaku etylu i pinoksadenu.

3. Nie stwierdzono istotnych różnic w ocenianych parametrach jakościowych ziarna pomiędzy zróżnicowanym sposobem aplikacji pinoksadenu z proheksadionem wapnia lub z chlorkiem chloromekwatu.

4. W zależności od roku badań łączne stosowanie pinoksadenu z CCC lub proheksadionem wapnia podwyższało lub obniżało zawartość białka, glutenu oraz wartość współczynnika Zeleneg’o w porównaniu do oddzielnego stosowania preparatów.

5. Na podstawie wykonanych analiz statystycznych nie stwierdzono różnic w stopniu twardości ziarniaków pomiędzy obiektami badań.

\section{Literatura / References}

Adamczewski K., Praczyk T. 1997. Regulatory wzrostu w rolnictwie. s. 167-187. W: „Regulatory wzrostu i rozwoju roślin, Zastosowanie w ogrodnictwie, rolnictwie, leśnictwie i w kulturach tkanek” Tom 2 (L.S. Jankiewicz, red.). PWN, Warszawa, 562 ss. ISBN 83-0112187-4.

Cacak-Pietrzak G., Ceglińska A., Leszczyńska D. 2005. Kształtowanie cech wypiekowych pszenicy uprawianej z zastosowaniem retardantów. [Baking values of winter wheat after retardants application]. Progress in Plant Protection/Postępy w Ochronie Roślin 45 (2): $597-600$.

Cacak-Pietrzak G., Ceglińska A., Leszczyńska D. 2006. Wpływ wybranych antywylegaczy na wartość wypiekową pszenicy ozimej. [Effect of some retardants on baking quality of winter wheat]. Progress in Plant Protection/Postępy w Ochronie Roślin 46 (2): 89-92.

Domaradzki K., Sekutowski T. 2004. Wpływ terminów nawożenia azotem i herbicydami na regulację zachwaszczenia i niektóre cechy jakościowe ziarna pszenicy ozimej. [Effect of nitrogen fertilization dates and herbicides on weed control and quality of winter wheat grain]. Progress in Plant Protection/Postępy w Ochronie Roślin 44 (2): 657-660.

Domska D., Rogalski L. 1993. Wpływ zróżnicowanego nawożenia azotem na wartość odżywczą białka żyta i pszenicy uprawianych w warunkach północno-wschodniej Polski. Fragmenta Agronomica 3 (39): 59-67.

Drzewiecki S., Pietryga J. 2002. Wpływ preparatu Antywylegacz płynny 675 SL stosowanego łacznie z nawozami dolistnymi na wybrane parametry jakościowe ziarna pszenicy ozimej. [Influence of growth regulator with foliar fertilizers on quality of winter wheat grain]. Progress in Plant Protection/Postępy w Ochronie Roślin 42 (2): 522-525.

Drzewiecki S., Pietryga J. 2003. Wpływ łącznego stosowania regulatora wzrostu Terpal C 460 SL z nawozami dolistnymi na cechy jakościowe ziarna pszenicy ozimej. [Influence of joint application of chlormequat chloride + ethephon (Terpal C 460 SL) and foliar fertilizers on quality parameters of winter wheat grain]. Progress in Plant Protection/Postępy w Ochronie Roślin 43 (2): $595-597$.

Dubis B., Borysewicz J. 2008. Wpływ nawożenia azotem na plon i technologiczną jakość wybranych odmian pszenicy ozimej. Fragmenta Agronomica 25 (1): 111-119.

Dziamba S., Mikos M. 1987. Wpływ flordimexu T (Camposan) i nawożenia na zawartość w ziarnie pszenżyta, pszenicy i żyta białka oraz lizyny w białku. Roczniki Nauk Rolniczych Seria A 107 (2): 9-21.

Fidanza M.A., Wetzel III H.C., Agnew M.L., Kaminski J.E. 2006. Evaluation of fungicide and plant growth regulator tank-mix programmes on dollar spot severity of creeping bentgrass. Crop Protection 25 (9): 1032-1038. DOI: 10.1016/j.cropro.2006.02.005.

Gil Z., Narkiewicz-Jodko M., Urban M. 2003. Wartość technologiczna ziarna pszenicy ozimej w zależności od stosowanych herbicydów. [Technological value of grain of winter wheat upon the applied herbicides]. Progress in Plant Protection/Postępy w Ochronie Roślin 43 (2): 628-631.

Gil Z., Narkiewicz-Jodko M., Urban M. 2004. Wpływ herbicydów na wartość przemiałową ziarna i wypiekową mąki odmian pszenicy ozimej. [Effect of herbicides on milling and baking value of winter wheat]. Progress in Plant Protection/Postępy w Ochronie Roślin 44 (2): 683-685.

Harasim E., Wesołowski M. 2013. Wpływ retardanta Moddus 250 EC i nawożenia azotem na plonowanie i jakość ziarna pszenicy ozimej. Fragmenta Agronomica 30 (3): 70-77.

Krawczyk M., Irzyk M., Mikos-Bielak M. 1995. Efekt działania kombinowanych regulatorów wzrostu na retardację wzrostu i jakość plonu zbóż. Materiały 35. Sesji Naukowej Instytutu Ochrony Roślin, część 2: 338-342.

Kucharski M., Sadowski J., Kieloch R. 2012. Adiuwanty w zabiegach przedwschodowych - wpływ na skuteczność diflufenikanu i jakości ziarna pszenicy ozimej. [Adjuvants in preemergence application - influence on diflufenican efficacy and quality of winter wheat grain]. Progress in Plant Protection/Postępy w Ochronie Roślin 52 (1): 51-54. DOI: 10.1499/ppp-20012-010.

Langensiepen M., Hanus H., Schoop P., Graesle W. 2008. Validating CERES-wheat under North-German environmental conditions. Agricultural Systems 97 (1-2): 34-47. DOI: 10.1016/j.agsy.2007.11.001.

Leszczyńska D., Grabiński J. 2003. Efektywność retardantów w zasiewach pszenicy ozimej w zależności od dawki i terminu aplikacji. [Effectiveness of retardants in winter wheat depending on dose and application term]. Progress in Plant Protection/Postępy w Ochronie Roślin 43 (2): 775-777. 
Leszczyńska D., Nieróbca P. 2004. Badania nad efektywnością działania retardantów w zasiewach pszenicy ozimej. [Studies on effectiveness of retardants in winter wheat]. Progress in Plant Protection/Postępy w Ochronie Roślin 44 (2): 906-908.

Maćkowiak W., Budzianowski G., Mazurkiewicz L., Paizert K., Woś H. 2001. Wpływ wzrastających dawek azotu i różnych sposobów stosowania regulatorów wzrostu na plonowanie pszenżyta ozimego. Biuletyn Instytutu Hodowli i Aklimatyzacji Roślin 220: 99-108.

Pawłowska J., Dietrych-Szóstak D. 1994. Efekt zastosowania regulatorów wzrostu w pszenżycie jarym. Materiały 34. Sesji Naukowej Instytutu Ochrony Roślin, część 2: 102-105.

Pietryga J., Drzewiecki S. 2003. Wpływ regulatora wzrostu Moddus 250 EC na wzrost, plonowanie i wybrane cechy technologiczne ziarna pszenicy ozimej. [Influence of growth regulator Moddus 250 EC (trinexapac etyl) on growth, yield and grain quality of winter wheat]. Progress in Plant Protection/Postępy w Ochronie Roślin 43 (2): 859-862.

Pietryga J., Drzewiecki S. 2004. Ocena działania regulatorów rozwoju roślin w zabiegu łączonym z nawozami dolistnymi w pszenicy ozimej. [Effectiveness of growth regulators mixed with foliar fertilizers applied in winter wheat]. Progress in Plant Protection/Postępy w Ochronie Roślin 44 (2): 1020-1023.

Podolska G., Stankowski S. 2001. Plonowanie i jakość ziarna pszenicy ozimej w zależności od gęstości siewu i dawki nawożenia azotem. Biuletyn Instytutu Hodowli i Aklimatyzacji Roślin 218/219: 127-136.

Podolska G., Stypuła G., Stankowski S. 2004. Plonowanie i wartość technologiczna ziarna pszenicy ozimej w zależności od intensywności ochrony zasiewów. Annales Universitatis Mariae Curie-Skłodowska, Section E - Agricultura 59 (1): 269-276.

Pruszyński S., Mrówczyński M. (red.). 2002. Łączne stosowanie agrochemikaliów. Instytut Ochrony Roślin, Poznań, 175 ss.

Romek B., Dzienia S. 1992. Wpływ retardantów na plon i jakość plonów pszenżyta ozimego. Materiały 32. Sesji Naukowej Instytutu Ochrony Roślin, część 2: 140-144.

Rothkaehl J. 1995. Właściwości technologiczne ziarna pszenicy. Metody oceny jakości ziarna pszenicy. Ośrodek Doradztwa Rolniczego, Piotrowice: $1-4$.

Woźnica Z. 1988. Wpływ Flordimexu TH na wyleganie i plony żyta przy zróżnicowanych dawkach azotu i gęstościach siewu. Roczniki Nauk Rolniczych Seria A 107 (3): 39-51. 